\title{
[ARTI GO RETRATADO] Translational research into gut microbiota: new horizons in obesity treatment
}

\section{Pesquisa translacional em microbiota intestinal: \\ novos horizontes no tratamento da obesidade}

Daniela M. Tsukumo, Bruno M. Carvalho, Marco A. Carvalho-Filho, Mário J. A. Saad

Received in Feb/05/2009 / Accepted in Feb/15/2009.

Published Arq Bras Endocrinol Metab. 2009;53(2):139-44

The authors of the above manuscript would like to apologize and retract it because in some paragraphs there are verbatim and unquoted sentences from others texts, although most of them, but not all, have been referenced. A corrected version of this review will be available in the next volume of Arq Bras Endocrinol Metab.

This retraction confirm the integrity of papers published in Arq Bras Endocrinol Metab. 


\title{
Translational research into gut microbiota: new horizons in obesity treatment
}

\author{
Pesquisa translacional em microbiota intestinal: \\ novos horizontes no tratamento da obesidade
}

Daniela M. Tsukumo', Bruno M. Carvalho', Marco A. Carvalho-Filho', Mário J. A. Saad'

\begin{abstract}
Obesity is a pandemic which has been rapidly developing for three decades. When a population is submitted to the same nutritional stress, some individuals are less suscept ble to dietinduced weight gain and hyperglycemia. This observation suggests that other mechanisms are involved which are not directly related to the human genome. The human gut contains an immense number of microorganisms, collectively known as the microbiota. Evidence that gut microbiota composition can differ between obese and lean humans has led to the speculation that gut microbiota can participate in the pathophysiology of obesity. Different mechanisms have been proposed to explain the link between gut flora an obesity. The first mechanism consists in the role of the gut microbiota to increase energy extr ction from i digestible dietary polysaccharides. The second, consists in the role of gut flora to modulate plasma lipopolysaccharide levels which triggers chronic low-grade inflam ation leading to obesity and diabetes. A third mechanism proposes that gut microbiota may hduce regulation of host genes that modulate how energy is expended and stored. However, further studies are needed to clarify a number of issues related to the relations $p$ betw en the ut microbiota and obesity. Arq Bras Endocrinol Metab. 2009;53(2):139-144.

Keywords

Obesity; gut flora; energy extraction; lipopolysaccharide

\section{RESUMO}

A obesidade é uma pandemia ue afeta milhões de pessoas em todo o mundo. Quando uma população é submetida a nesmo estresse nutricional, alguns indivíduos são menos suscetíveis ao ganho de pe so induzido ela dieta e à hiperglicemia. Essa observação sugere que outros mecanismos náo diretanente relacionados ao genoma humano estejam envolvidos. 0 intestino human e colenizado por milhões de bactérias, que coletivamente constituem a flora comensal no rmal. A evidência de que a composição da flora intestinal pode ser diferente em humanos magros e obesos levou à especulação de que a flora intestinal pode participar na fisiopatologia da obesidade. Diferentes mecanismos foram propostos para tentar explicar a correlação entre flora intestinal e obesidade. 0 primeiro mecanismo consiste no papel da flora intestinal na extração de energia de polissacarídeos não digeríveis. 0 segundo mecanismo envolve a modulação dos níveis de lipopolissacarídeo pela flora intestinal, o que desencadeia uma inflamação crônica subclínica que acarreta obesidade e diabetes. Um terceiro mecanismo propõe que a flora intestinal pode induzir a regulação de genes do hospedeiro que modulam como a energia é gasta e armazenada. Entretanto, estudos adicionais são necessários para estabelecer o papel da flora intestinal no desenvolvimento da obesidade. Arq Bras Endocrinol Metab. 2009;53(2):139-144.
\end{abstract}

Descritores

Obesidade; flora intestinal; extração de energia; lipopolissacarídeo

Correspondence to:

Mário J. A. Saad

Departamento de Clínica Médica, FCM-Unicamp, Cidade Universitária Zeferino Vaz 13081-970 - Campinas, SP, Brasil msaad@fcm.unicamp.br

Received in Feb/05/2009 Accepted in Feb/15/2009 


\section{INTRODUCTION}

$\mathrm{O}$ besity is increasing among humans and is becoming a pandemic which has been rapidly developing for three decades (1). Obesity results from alterations in the body's regulation of energy intake, expenditure, and storage. An increase in intake of energy-dense foods, specially combined with reduced physical activity, surely contributes to the high prevalence of obesity (2). However, when a population is submitted to the same nutritional stress, some individuals are less susceptible to diet-induced weight gain and hyperglycemia $(3,4)$. This observation suggests that other mechanisms are involved which are not directly related to the human genome.

The human gut contains an immense number of microorganisms, collectively known as the microbiota. This community is dominated by anaerobic bacteria and includes $\sim 500-1,000$ species whose collective genomes are estimated to contain 100 times more genes than our own human genome $(5,6)$. Our gut microbiota can be pictured as a microbial organ which contributes to our homeostasis (7); its functions are multiple and largely diverse.

Recently, gut microbiota has been shown to arece fat storage and energy harvesting (8), which suggests that intestinal microorganisms may play a the development of obesity. In this a icle, ne revie the published evidence supporting the oten tal rol of the gut microbiota in the development of besity.

\section{NORMAL GUT MICROBIOTA}

Commensal bacteria are pres it in vast number in the gastrointestinal tract. Reside bacter outnumber human somatic and germ cells ten-fold and represent a combined microbial genome cil in excess of human genome (9).

Acid bile an pancreatic secretions hinder the colonization of the stomach and proximal intestine by most bacteria. The colon is colonized with approximately $10^{12}$ organisms/g intestinal content (Figure 1). Recently, it was demonstrated that Bacteroidetes and Firmicutes account for more than $90 \%$ of all phylotypes of Bacteria. More than $90 \%$ of the bacterial population are obligate anaerobes, predominant species being: Bacteroides, Eubacterium, Bifidobacterium, Fusobacterium, Peptostreptococcus among other.

The intestinal flora plays an important role in normal gut function and maintenance of the host's health. The benefits of commensal bacteria are well known:

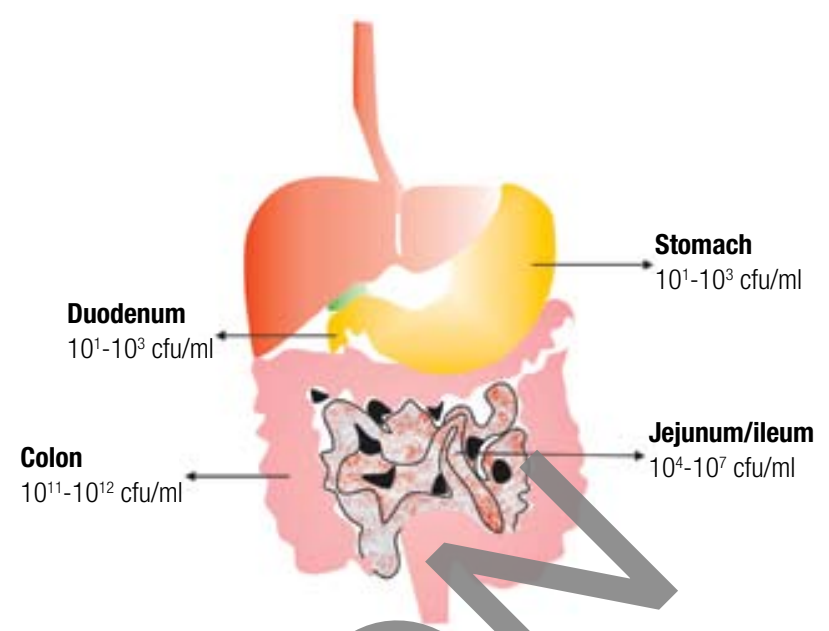

$\mathrm{cfu}=$ colony-forming unit.

Figure 1. Relative concentrations of bacteria at various locations within the gut.

help us to diges cellu ose an salvage energy, form a natural de ense barrier which is considered to be essential in the cevelopment and maturation of mucosal and systemic immune systems. The gut microbiota is composed of potentially pathogenic bacteria besides numerous health promoting nonpathogenic microorganisms.

Despite our limited understanding of the compositron of the indigenous gut microbiota, evidence suggests that it is established within the first year of life. The fetal gut is sterile but colonization begins immediately after birth and is influenced by the mode of delivery, infant diet, hygiene levels and medication (10). Intestinal colonization begins at delivery, when the infant is exposed to vaginal flora, maternal fecal bacteria and environmental bacteria, and is likely to continue beyond the perinatal period, at least up to the age of 12-24 months, before a stable unique flora is established (11-13). Studies have shown that the adopted delivery method can have an influence. Infants delivered vaginally have earlier colonization with both Bifidobacterium and Lactobacillus, whereas infants delivered by cesarean section can have colonization with these beneficial organisms delayed by up 30 days (10).

As indicated above, the assembly of the gut microflora commences at birth, but its composition will undergo dramatic changes during postnatal development. The diet is clearly a key factor which regulates the sequence and the nature of colonization. Enterobacteria and bifidobacteria represent early colonizers, although differences in intestinal flora composition occur between breast- and formula-fed infants (14). In breast-fed infants, Bifidobacterium is a primary organism and the microflora produces high amounts of acetate and lac- 
tate restricting the growth of potential pathogens such Escherichia coli and Clostridium perfringens. In addition, colonization is affected by gestational age. Premature infants in the neonatal intensive care unit undergo a delayed colonization with a limited number of bacterial species that tend to be more virulent $(15,16)$.

Although the composition of microbiota varies along the length of the gut and during the life of the host, it is quite stable during a considerable part of normal human lifespan. The transformation to adult-type microbiota is likely triggered by multiple host and external factors $(17,18)$, including the effects of the microbiota itself, developmental changes in the gut environment, and transition to an adult diet.

A limited number of studies have indicated that the colonic microflora changes with ageing. The principal microbiological differences between adults and elderly were the occurrence of higher numbers of enterobacteria and a lower number of anaerobe populations in the elderly group (19). Bifidobacterial species, which are viewed as being protective, dramatically decreases with age, whereas clostridia and enterobacterial, which are viewed as being detrimental to health, increase $(20,21)$.

The gut microflora of one person can differ markedly from another and comparative studies of adults with varying degrees of relatedness have shown that the host ge type is more important than diet, age, an lifesp $\mathrm{n}$ in $\mathrm{d}$ termining the composition of the gut microbiota (19,22).

Studies using germ-free mice have stown that gut microbiota is critical for main a ing norma gastrointestinal and immune function and normal digestion of nutrients. Germ-free a imals are more susceptible to infection and have reduced vascularity, digestive enzyme activity, muscle al thickness, cytokine production, mucosal associated $\mathrm{mph}$ hid tissue, motility and serum imn noglob ulin levers (9).

\section{GUT MICROBIOTA AND OBESITY}

\section{Extraction of additional calories from ingested food}

Given the worldwide epidemic of obesity, there is interest in how interactions between human and gut microbiota may contribute to the development of obesity. Recent evidence suggests that the trillions of bacteria that normally reside within the human gut affect nutrient acquisition and energy regulation. Furthermore, bacterial lypopolysaccharide derived from intestinal microbiota may act as a triggering factor linking inflammation to high-fat diet-induced obesity (Figure 2).

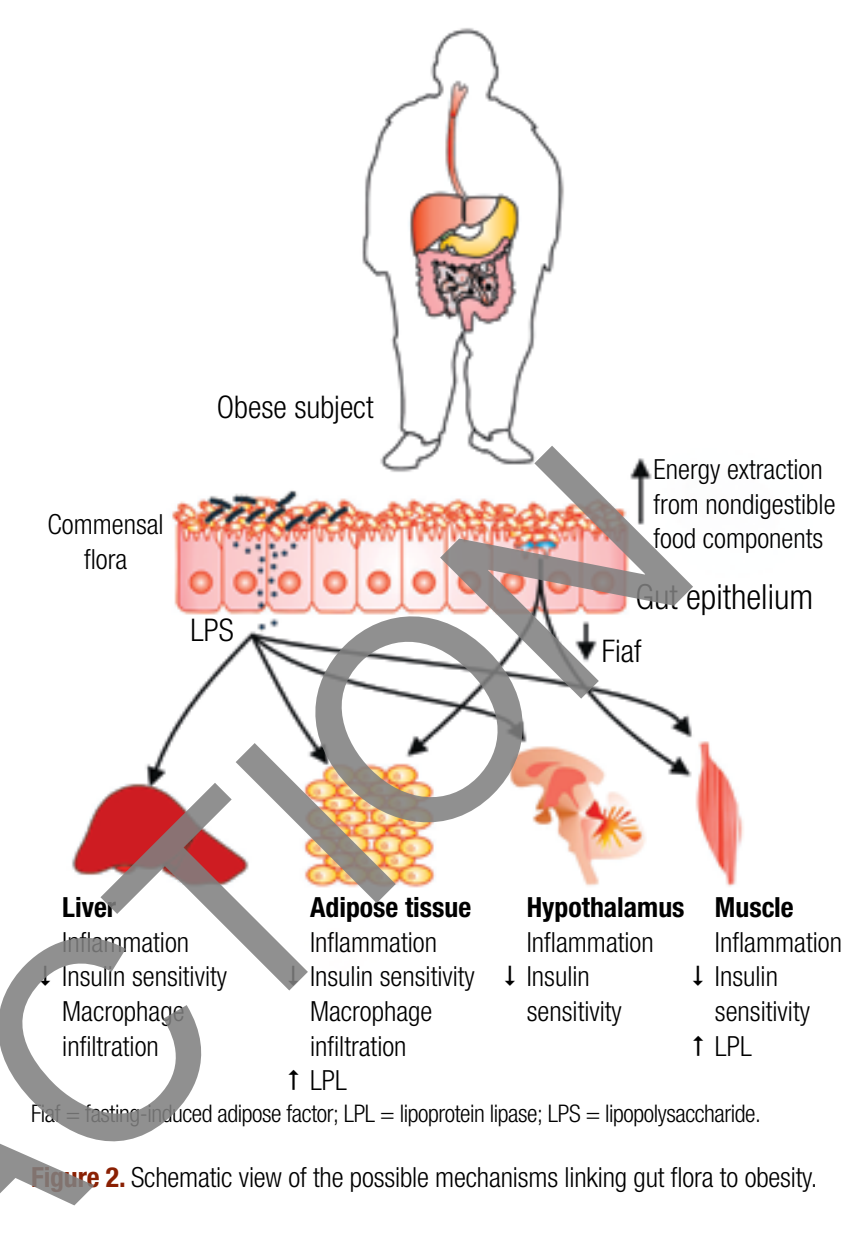

Backhed and cols. demonstrated that conventionally reared mice have a higher body fat content than germ-free mice even though they consume less food than their germ-free counterparts (23). Along the same line, it was later shown that colonization of germ-free mice with an obese microbiota resulted in a significant greater increase in total body fat than colonization with lean microbiota (24). This study also characterized the distal gut microbiomes of obese leptin-deficient $(o b / o b)$ mice and their lean $(o b /+$ and $+/+)$ littermates and it was found that obese mice have a higher proportion of intestinal Firmicutes with a corresponding reduction in the numbers of Bacteroidetes. These investigators showed that the microbiota of obese mice was rich in genes encoding enzymes that break down otherwise indigestible dietary polysaccharides. They also found more end products of fermentation and fewer calories in the feces of the obese mice, leading them to speculate that the gut microbiota in these mice facilitate the extraction of additional calories from ingested food.

Ley and cols. also demonstrated that obesity can be associated with altered gut microflora in a rodent model (25). The comparison of the gut microbiota of 
$o b / o b$ mice versus lean mice showed that the relative abundance of the Bacteroidetes in $o b / o b$ mice was $50 \%$ lower, whereas that of the Firmicutes was $50 \%$ higher (Figure 3). In obese humans, the same team of investigators reported a decrease in the relative proportion of Bacteroidetes when compared to lean individuals (26). Additionally, when obese patients lost weight over a one-year period, the proportion of Firmicutes became similar to that of lean individuals.

Further studies are needed to clarify a number of issues related to the relationship between gut microbiota and obesity. It is not clear whether the small increase of energy extraction can actually lead to a meaningful body weight gain within a short period of time, as suggested in the gut flora transplantation studies. Furthermore, it has been reported in other studies that a diet rich in non-digestible fibers decreases body weight, fat mass and the severity of diabetes $(27,28)$.

Additionally, important questions remain unanswered. The first is why and how the make-up of the microbiota is shifted by differences in body weight. If a host organism had the ability to change its microbiota so as to increase caloric extraction, it would seem most adaptive to do so when facing famine conditions and losing weight. However, exactly the opposite was (cmonstrated as the microbiota seems to be more effici
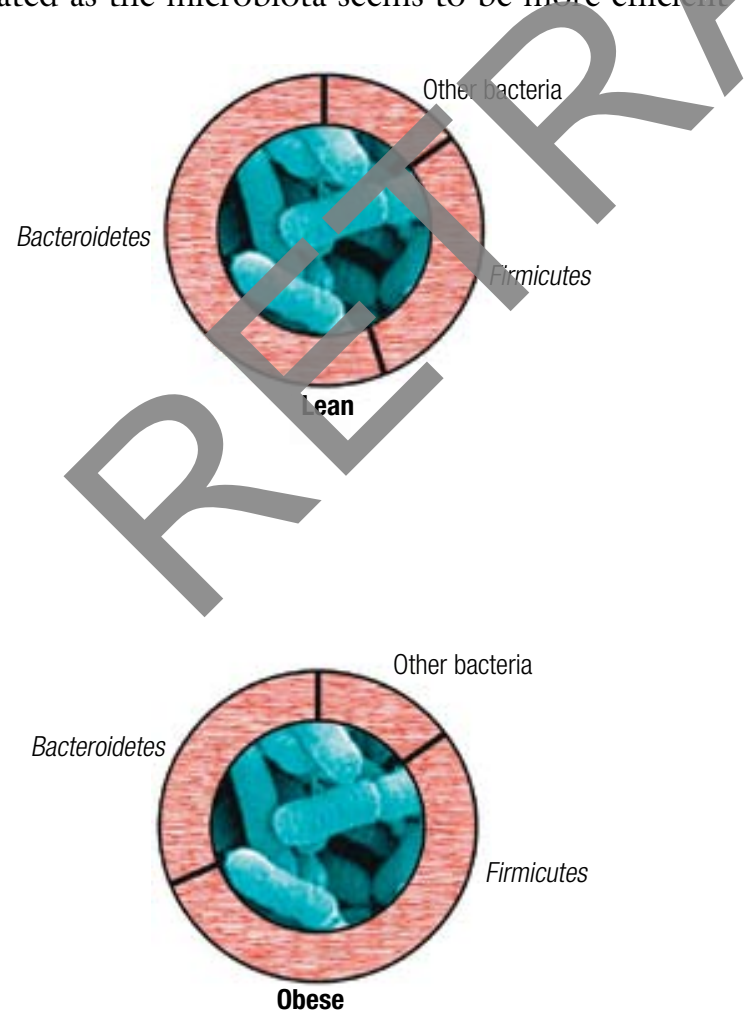

Figure 3. Relative proportion of firmicutes and bacteroidetes in lean and obese mice. in obese humans who already have the most stored energy (26). Moreover, there is also the question of how conditions in the host organism could change the make-up of the microbiota.

\section{Induction of subclinical inflammation}

Recently, a new hypothesis linking gut microflora to metabolic homeostasis have been proposed (Figure 2). On the basis of the recent demonstration, that obesity and type 2 diabetes are associate with low-grade chronic systemic inflammation (29-33) in the liver, adipose tissue and hypothalants, Cani and cols. (34) hypothesized that breterial lipop lysaccharide (LPS) derived from gram- egative bacteria residing in the gut microbiota acts as a riggering factor linking inflammation to high fat chet-in luced d betes and obesity. They found th high-fat diet feeding resulted in a significant podution of the dominant bacterial populations within the gut microflora. A reduction in the number of bilidobacteria, Eubacterium rectal-Clostridium coccoides grotp and Bacteroides, favoring an increase in the gram- egative to gram-positive ratio was observed. This moulation of gut microflora was associated with significant increase in plasma lipopolysaccharide, fat mass, body weight gain, liver hepatic triglyceride accumulation, insulin resistance and diabetes. Another study has shown that treatment of rats with polymyxin $\mathrm{B}$, an antibiotic that specifically targets gram-negative organisms, reduced LPS expression and hepatic steatosis (35).

Human studies have provided support for these findings. It was found that plasma lypopolysaccharide levels were significantly higher in the age-matched type 2 diabetes patient group than in individuals without diabetes (36). This study reinforced the hypothesis that lypopolysaccharide may act as a gut microbiota-related factor involved in the development of type 2 diabetes and obesity in humans.

A more recent study reported that modification of gut microbiota by norfloxacin and ampicillin, two antibiotics, ameliorated oral glucose tolerance and reduced hepatic steatosis in $o b / o b$ mice (37). Cani and cols. (38) have also demonstrated that the modulation of gut flora by antibiotic treatment lowers plasma LPS levels, gut permeability, and the occurrence of visceral adipose tissue inflammation and macrophage infiltration in high-fat-fed mice. This effect was correlated with reduced glucose intolerance and body weight gain. 
Regulation of host genes that modulate how energy is expended and stored

As described above, it has been recently demonstrated that control mice have a $40 \%$ higher body fat content and $\sim 50 \%$ higher gonadal fat content than germ-free mice (23). In this study, when the distal gut microbiota from the normal mice was then transplanted into the gnotobiotic mice, there was a $60 \%$ increase in body fat within 2 weeks. To clarify possible mechanisms of this effect, the authors showed that the microbiota promoted absorption of monosaccharides from the gut and induced hepatic lipogenesis in the host, responses mediated by 2 proteins: carbohydrate response element-binding protein (ChREBP) and liver sterol response element-binding protein type-1 (SREBP-1) (23).

In an interesting experiment, using genetically modified (fasting-induced adipocyte factor [Fiaf]knockout) mice, the same authors showed that gut microbes suppress intestinal Fiaf, also known as angiopoietin-like protein 4 (Figure 2). Fasting-induced adipocyte factor inhibits lipoprotein lipase activity, thereby catalyzing the release of fatty acids from lipoproteinassociated triacylglycerols, which are then taken muscle and adipose tissue. In the study, Fiaf supp ression resulted in increased lipoprotein lipase activity adipocytes and promoted storage of cal ines as at, leac ing the authors to postulate that energy res nation by the gut microbiota occurs throrgh at leas three interrelated microbial mechanism . a fermentation of indigestible dietary polysaccharides to absorbable forms; b) intestinal absorption of monosacchades and shortchain fatty acids with their subsequent conversion to fat within the liver and regulation of host genes that promote dep sition of fat li ocytes (23).

In addition, Bached and cols. (39) have investigated the mechanisu(s) underlying resistance to obesity in germ-free mice, yy studying germ-free mice consuming a high-fat and sugar-rich diet. They determined that germ-free animals were protected from diet-induced obesity by 2 complementary but independent mechanisms that result in increased fatty acid metabolism: (1) elevated levels of Fiaf trigger the production of peroxisome proliferator-activated receptor gamma coactivator, which is known to increase the expression of genes encoding regulators of mitochondrial fatty acid oxidation; and (2) the activity of AMPK (adenosine monophosphate-activated protein kinase), an enzyme that monitors cellular energy status, is increased. These findings suggest that the gut microbiota can affect both sides of the energy balance equation, influencing energy harvest from dietary substances (Fiaf) and affecting genes that regulate how energy is expended and stored.

\section{CONCLUSION}

Evidence that gut microbiota composition can differ between obese and lean humans has led to the speculation that gut microbiota cath participate in the pathophysiology of obesity. Different hechanisms have been proposed to explain the link between gut flora and obesity. The first mechanisn consists in the role of gut microbiota to ncrease encery extraction from indigestible dietary polysacchar des. The second, consists in the role of git flora to modulate plasma LPS levels which triggers chronic ow-grade inflammation leading obesity and diabetes. A third mechanism propeses that gut microbiota may induce regulation of host genes that modulate how energy is expended and stored. However, many questions are still unanswered. First, it is not clear whether small changes in caloric xtraction can actually lead to meaningful differences in body weight. Furthermore, it is essential to prove hether the differences observed in gut microbiota of obese people are the cause or consequence of obesity.

The human intestine is more densely populated with microorganisms than any other organ and manipulation of the gut microbiota may represent a new approach for treating obesity. However, the role of prebiotics, probiotics and antibiotics in the modulation of gut microbiota in obesity is unknown. Probiotics are live organisms that are frequently used as dietary regulators to influence the gut microbiota composition. Prebiotics are non-digestible oligosaccharides that are fermented by gut flora enhancing the growth of beneficial commensal microorganisms. In the future, prebiotics, probiotics and antibiotics may be used to modulate gut flora and perhaps they will have a role in the treatment of obesity and its complications.

Disclosure: No potential conflict of interest relevant to this article was reported.

\section{REFERENCES}

1. Hill JO, Wyatt HR, Reed GW, Peters JC. Obesity and the environment: where do we go from here? Science. 2003; 299(5608):853-5. 
2. Hill JO. Understanding and addressing the epidemic of obesity: an energy balance perspective. Endocr Rev. 2006;27(7):750-61.

3. Levin BE, Keesey RE. Defense of differing body weight set points in diet-induced obese and resistant rats. Am J Physiol. 1998;274(2 Pt 2):R412-9.

4. Tappy L. Metabolic consequences of overfeeding in humans. Curr Opin Clin Nutr Metab Care. 2004;7(6):623-8.

5. Xu J, Gordon JI. Inaugural Article: Honor thy symbionts. Proc Natl Acad Sci USA. 2003;100(18):10452-9.

6. Cani PD, Delzenne NM. Gut microflora as a target for energy and metabolic homeostasis. Curr Opin Clin Nutr Metab Care. 2007;10(6):729-34.

7. Bocci V. The neglected organ: bacterial flora has a crucial immunostimulatory role. Perspect Biol Med. 1992;35(2):251-60.

8. DiBaise JK, Zhang $H$, Crowell MD, Krajmalnik-Brown $\mathrm{R}$, Decker GA, Rittmann BE. Gut microbiota and its possible relationship with obesity. Mayo Clin Proc. 2008;83(4):460-9.

9. Shanahan F.The host-microbe interface within the gut. Best Pract Res Clin Gastroenterol. 2002;16(6):915-31.

10. Gronlund MM, Lehtonen OP, Eerola E, Kero P. Fecal microflora in healthy infants born by different methods of delivery: permanent changes in intestinal flora after cesarean delivery. J Pediatr Gastroenterol Nutr. 1999;28(1):19-25.

11. Favier CF, Vaughan EE, De Vos WM, Akkermans AD. Molecular monitoring of succession of bacterial communities in human neonates. Appl Environ Microbiol. 2002;68(1):219-26.

12. Midtvedt AC, Midtvedt T. Production of short chain fatty acids by the intestinal microflora during the first 2 years of human life. $J$ Pediatr Gastroenterol Nutr. 1992;15(4):395-403.

13. Zoetendal EG, Akkermans AD, De Vos WM. Temperature gradient gel electrophoresis analysis of 16S rRNA from human fec ples reveals stable and host-specific communities of active bacteria. Appl Environ Microbiol. 1998;64(10):3854-9.

14. Mountzouris KC, McCartney AL, Gibson GR. Intestinal microfi of human infants and current trends for its yutrition modu tion. Br J Nutr. 2002;87(5):405-20.

15. Kosloske AM. Epidemiology of necrotizing enterocolitis. Acta Paediatr Suppl. 1994;396:2-7.

16. Orrhage K, Nord CE. Factors controlling the bacterial colonization of the intestine in breastfed infants. Acta Paediatr Suppl. 1999;88(430):47-57.

17. Gorbach SL. Intestinal microflora. Gastroenterology. 1971; 60(6):1110-29.

18. Mackie RI, Sghir-A Gaskins HR. De lopmental microbial ecology of the neonatal gast intestinal tract. Am J Clin Nutr. 1999;69(5):035S-10 $5 \mathrm{~s}$

19. Hopkins M Sharp R, Mafarlane GT. Age and disease related changes in in tes inal bacterial populations assessed by cell culture, 16S rRNA abundance, and community cellular fatty acid profiles. Gut. 2001;48(2), 98-205.

20. Gorbach SL, Nahas L, Lerner PI, Weinstein L. Studies of intestinal microflora. I. Effects of diet, age, and periodic sampling on numbers of fecal microorganisms in man. Gastroenterology. 1967;53(6):845-55.

21. Mitsuoka T. Recent trends in research on intestinal flora. Bifidobacteria Microflora. 1982;1:3-24.

22. Zoetendal EG, Akkermans ADL, Akkermans-van WM, de Visser JAGM, de Vos WM. The host genotype affects the bacterial community in the human gastrointestinal tract. Microb Ecol Health Dis. 2001;13(3):129-34.
23. Backhed F, Ding H, Wang T, Hooper LV, Koh GY, Nagy A, et al. The gut microbiota as an environmental factor that regulates fat storage. Proc Natl Acad Sci USA. 2004;101(44):15718-.

24. Turnbaugh PJ, Ley RE, Mahowald MA, Magrini V, Mardis ER, Gordon JI. An obesity-associated gut microbiome with increased capacity for energy harvest. Nature. 2006;444(7122):1027-31.

25. Ley RE, Backhed F, Turnbaugh P, Lozupone CA, Knight RD, Gordon JI. Obesity alters gut microbial ecology. Proc Natl Acad Sci USA. 2005;102(31):11070-5.

26. Ley RE, Turnbaugh PJ, Klein S, Gordon JI. Microbial ecology: human gut microbes associated with obesity. Nature. 2006;444(7122):1022-3.

27. Cani PD, Joly E, Horsmans $Y$, Delzenn NM. Oligofructose promotes satiety in healthy human: a pilot study. Eur J Clin Nutr. 2006:60(5):567-72.

28. Cani PD, Neyrinck AM, Maton N Delzenne NiM. Oligofructose promotes satiety in rats fed a high - diet: invoivernent of glucagon-like Peptide-1. Obes Bes. 2005;13,6:1000-7.

29. Wellen KE, Hotamislig i GS. Inflam ation, stress, and diabetes. J Clin Invest 2005;115 5):1111-9.

30. Caricilli AM, Nascim to PH, Paul JR, Tsukumo DM, Velloso LA, Carvalheira $B$ et a Inhibition of toll-like receptor 2 expression impoves insulin sensitivity and signaling in muscle and white adipose tissue mice fed a high-fat diet. J Endocrinol. 2008;199(3) 399-406.

31. Carvalho-Filno MA, Ueno M, Hirabara SM, Seabra AB, Carvalheira JB, de Oliveira MG, et al. S-nitrosation of the insulin receptor, insulin receptor substrate 1, and protein kinase B/Akt: a novel mechanism of insulin resistance. Diabetes. 2005;54(4):959-67.

2. Prada $P$, Zecchin HG, Gasparetti AL, Torsoni MA, Ueno M, Hirata $A$, et al. Western diet modulates insulin signaling, c-Jun $\mathrm{N}$-terminal kinase activity, and insulin receptor substrate-1ser307 phosphorylation in a tissue-specific fashion. Endocrinology. 2005;146(3):1576-87.

33. Tsukumo DM, Carvalho-Filho MA, Carvalheira JB, Prada PO, Hirabara SM, Schenka AA, et al. Loss-of-function mutation in Toll-like receptor 4 prevents diet-induced obesity and insulin resistance. Diabetes. 2007;56(8):1986-98.

34. Cani PD, Amar J, Iglesias MA, Poggi M, Knauf C, Bastelica D, et al. Metabolic endotoxemia initiates obesity and insulin resistance. Diabetes. 2007;56(7):1761-72.

35. Pappo I, Becovier H, Berry EM, Freund HR. Polymyxin B reduces cecal flora, TNF production and hepatic steatosis during total parenteral nutrition in the rat. J Surg Res. 1991;51(2):106-12.

36. Creely SJ, McTernan PG, Kusminski CM, Fisher M, Da Silva $\mathrm{NF}$, Khanolkar M, et al. Lipopolysaccharide activates an innate immune system response in human adipose tissue in obesity and type 2 diabetes. Am J Physiol Endocrinol Metab. 2007;292(3):E740-7.

37. Membrez $M$, Blancher $F$, Jaquet $M$, Bibiloni $R$, Cani PD, Burcelin $R G$, et al. Gut microbiota modulation with norfloxacin and ampicillin enhances glucose tolerance in mice. Faseb $\mathrm{J}$. 2008;22(7):2416-26

38. Cani PD, Bibiloni R, Knauf C, Waget A, Neyrinck AM, Delzenne $\mathrm{NM}$, et al. Changes in gut microbiota control metabolic endotoxemia-induced inflammation in high-fat diet-induced obesity and diabetes in mice. Diabetes. 2008;57(6):1470-81.

39. Backhed F, Manchester JK, Semenkovich CF, Gordon JI. Mechanisms underlying the resistance to diet-induced obesity in germfree mice. Proc Natl Acad Sci USA. 2007:104(3):979-84. 